\title{
小児滲出性中耳炎とアデノイド
}

\author{
藤 田 明 彦

\section{Adenoids and Otitis Media with Effusion}

\author{
Akihiko Fujita \\ (Kurashiki Central Hospital)
}

\begin{abstract}
To clarify the etiological role of adenoids in OME, the effects of adenoidectomy on hearing, Eustachian tube function and nasal sinusitis were examined. Adenoids were found to have no influence on tubal opening pressure or patency of the Eustachian tube in a static condition. Active function of the tube during swallowing, however, was improved significantly by adenoidectomy. In addition, adenoidectomy improved nasal sinusitis, and in these patients, hearing and active tubal function were satisfactory. These results suggest that adenoidectomy cures OME partly via improvement of pathological conditions of the nasopharynx represented by nasal sinusitis.
\end{abstract}

Key words: otitis media with effusion, adenoids, Eustachian tube, sinusitis

はじぬに

小巟滲出性中耳炎に対するアデノイド切除術 の歴史は1870年の Meyer の報告1) 以来，すで に100年余りが経過している. しかし近年，その 治療効果を疑問視する意見 ${ }^{2)}$ ４） も見られ，乙れ を有効とするもの ${ }^{5)}$ ） との間で，なお結論を見 るに至っていない，てのような論争の原因は， 一つにはアデノイド切除の効果が中耳側からだ けで評価され，その中間に位置する耳管，更に は副鼻腔炎などいわゆる上気道炎との関係でと らえられていないととによる。また滲出性中耳 炎の評価の方法が一定して扔らず，なかでも近 年用いられるティンパノグラムは病態の検出に やや鋭敏すぎる短所を持つといえる.

アデノイド切除術に対する疑問点をあげる と，1）滲出性中耳炎の治療としての有効性, 2 ) アデノイド切除と耳管機能との関係，3）
副鼻腔炎に代表される鼻咽腔の炎症を改善しう るか，などである，今回，乙れらの点を明らか にする目的で，小児滲出性中耳炎 150 例を対象 に比較的短期間での観察を行ったので報告す る.

小児淕出性中耳炎とアデノイド肥大， 副鼻腔炎の合併頻度

アデノイド肥大の判定は, 従来から指頭検査 あるいは上咽頭の側面レ線像に基づいて行われ て来たが，近年は内視鏡検査の有用性が指摘さ れている8 . 今回は 4 歳から 7 歳までの小児滲 出性中耳炎 150 例を対象とし，内視鏡または上 咽頭側面レ線像の少なくとも一方でアデノイド 肥大を認めるあのを，「肥大あり」とした。 ま た，副鼻腔炎の合併の有無をウォータース法撮 影による鼻レ線像で判定した。

その結果は，アデノイド肥大を認めるもの85 
\%，副鼻腔炎を認めるあの78\%といずれも高率 であり，両者を合併するあのあ68\%にみられた （図 1 ）。即ち，小児滲出性中耳炎ではアデノィ ドあるいは副鼻腔炎に代表される鼻咽腔の炎症 状態が一般に存在するととがわかり，病因とし て重視すべきと考えられた．また，レ線的にア デノイド肥大なしと判定された症例のうち，そ の57\%は，内視鏡的にはアデノイドによる耳管 咽頭口の圧迫像が観察され，本検査法の有用性 が確認された(表 1 ).

\section{アデノイド切除術の港出性中耳炎に対}

\section{する効果}

アデノイド切除術の滲出性中耳炎に対する効 果の判定にはいくつかの困難さがあり，乙の理 由として，1）小児滲出性中耳炎は加齢による 自然治瘺の傾向があり，長期観察例の中には治 療之無関係に正常化する例があること，2）ア デノイドそのものも加齿で自然に退縮し，長期 の観察ではこの要素が混入してくること，3) 術後の滲出性中耳炎の改善を客観的に判定する ことが難しいこと，などがあげられる，従って 今回，アデノイド切除術の効果判定を，6ケ月

\begin{tabular}{|c|c|c|}
\hline 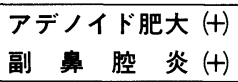 & & $68 \%$ \\
\hline $\begin{array}{l}\text { アデノイド肥大 }(+) \\
\text { 副 } \\
\text { 䋰 }\end{array}$ & $17 \%$ & \\
\hline $\begin{array}{l}\text { アデノイド肥大 }(-) \\
\text { 副 }\end{array}$ & $10 \%$ & \\
\hline $\begin{array}{l}\text { アデノイド肥大 }(-) \\
\text { 副 鼻 焱 }(-)\end{array}$ & $5 \%$ & \\
\hline
\end{tabular}

図 1 滲出性中耳炎とアデノイド肥大, 副鼻 腔炎の合併頻度

表 1 耳管咽頭口の内視鏡所見とレントゲン 所見の比較

\begin{tabular}{|c|c|c|c|}
\hline & \multicolumn{2}{|c|}{ レントゲン所見 } \\
\hline & & $\begin{array}{l}\text { アデノイド } \\
\text { 肥大なし }\end{array}$ & $\begin{array}{l}\text { アデノイド } \\
\text { 肥大あり }\end{array}$ \\
\hline \multirow{2}{*}{$\begin{array}{l}\text { 内視鏡 } \\
\text { 所 見 }\end{array}$} & $\begin{array}{l}\text { アデノイド } \\
\text { 肥大なし }\end{array}$ & $\begin{array}{l}23 \text { 例 } \\
(43 \%)\end{array}$ & 5例 \\
\hline & $\begin{array}{l}\text { アデノイド } \\
\text { 肥大 大り }\end{array}$ & $\begin{array}{l}30 \text { 例) } \\
(57 \%)\end{array}$ & 92例 \\
\hline
\end{tabular}

間という比較的短期間で行い，効果判定は純音 聴力検査を用いて切除術の効果を出来るだけ正 確に判定しようとした。

<対象と方法 $>$

滲出性中耳炎患児95例127耳（ 5 歳～ 7 歳）を 次の 2 群に分けた.

1. アデノイド切除+チューブ留置群 50 例 74 耳 (平均6.0歳)

2. チューブ留置単独群45例53耳（平均 6.2 歳）

アデノィド切除は全例全麻下に行った。 チュ 一ブ留置術はアデノィド切除之同時に行うか, または別に局麻下に行い，全例グロメットタイ プのチューブを挿入した。 また，両群とも対象 の 9 割以上にアデノイド肥大が認められた（表 2 ). 純音聴力検査は治療前, 治療後 1 週目, 2，4，6 ケ月目に行い，4 分法で表示した. 結果の比較は次の 2 つの条件下で行った.

[条件 1] 全症例で比較した場合

この際，治療前の聴力が良い症例では治療に よる聴力改善が少なく，聴力を治療効果の判定 に用いるのは不適当な症例といえる. またチュ 一ブ留置例では，アデノイド切除の有無にかか わらず良好な聴力が期待出来るため，アデノイ ド切除術の効果を知るととが難しい.

[条件 2] 治療前の聴力レベルが $20 \mathrm{~dB}$ 以上 の難聴で，かつ 6 ケ月以内にチューブが脱落し た症例で比較した場合

この条件下では，アデノイド切除術のみの聴 力に対する効果が最むよく示されると考えられ た。

表 2 各治療群におけるアデノイド肥大の有無

\begin{tabular}{|c|c|c|}
\hline & アデノイド肥大(+) & 肥大(一または不明 \\
\hline $\begin{array}{c}\text { アデノイド切除+ } \\
\text { チューブ留群 } \\
\text { (74 }\end{array}$ & 72耳 (97\%) & 2耳 \\
\hline 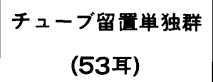 & 48耳 $(91 \%)$ & 5耳 \\
\hline
\end{tabular}




\section{<結 果 >}

[条件 1] 全症例で比較した場合

アデノイド切除十チューブ留置群（74耳）で は，術前の平均聴力が $29.5 \mathrm{~dB}$ であったあの が，術直後から 6 ケ月間，安定した聴力改善が 得られ，6 ケ月目の平均聴力は $13.7 \mathrm{~dB}$ ，聴力 改善は $15.8 \mathrm{~dB}$ に達した. また， 6 ケ月目の 聴力レベルが $20 \mathrm{~dB}$ 未満に改善した例は，74耳 中59耳（80\%）であった。このことは小児滲出 性中耳炎に打ける本治療の 6 ケ月間での安定し た聴力改善効果を示すあのと言える(図 2).

一方，チューブ留置単独群（53耳，術前の聴 カレベル $29.8 \mathrm{~dB})$ では, 術直後の著明な聴力 改善は前者と同様であるが，4 ケ月目から平 均聴力の悪化が見られ，最終的な聴力改善は

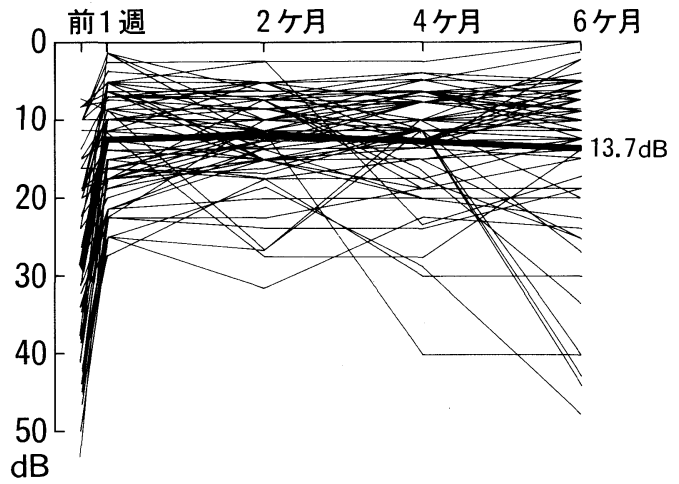

図 2 アデノイド切除十チューブ留置群 (74耳) の聴 力の推移, 聴力の平均を太線で示す

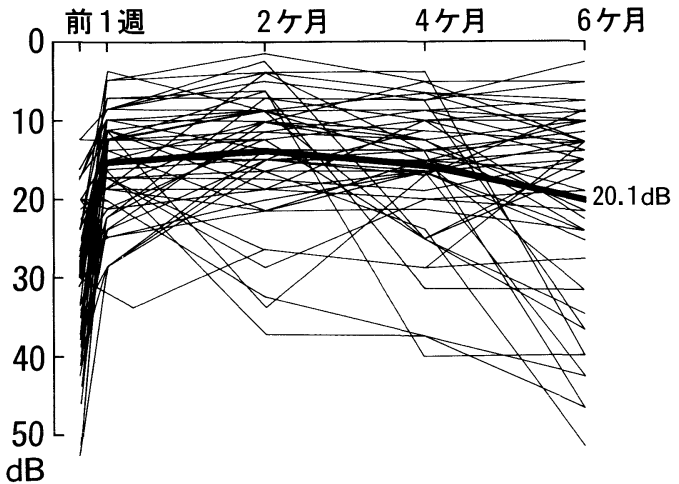

図 3 チューブ留置単独群（53耳）の聴力の推移
$9.7 \mathrm{~dB}$, 聴力改善例（聴カレベル $20 \mathrm{~dB}$ 末満） 屯53耳中の 32 耳（60\%）にとどまった。この治 療法によっても，6 ケ月間は満足すべき聴力が 得られるととがわかるが，4 ケ月目からみられ る聴力の悪化は，チューブ脱落の要因によると 考えられた(図 3 ).

[条件 2] 治療前の聴力レベルが $20 \mathrm{~dB}$ 以上 の難聴で，かつ 6 ケ月以内にチューブが脱落し た症例で比較した場合

アデノイド切除チューブ留置群（31耳，治 療前の平均聴力レベル $34.9 \mathrm{~dB})$ では, 術直後

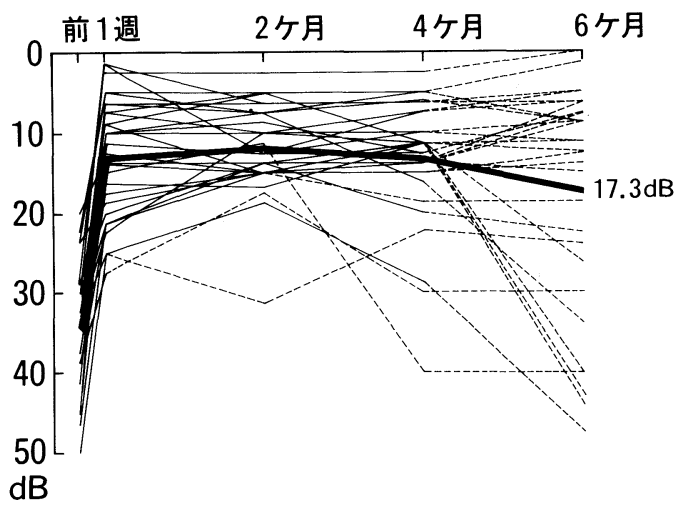

図 4 アデノイド切除+チューブ留置群（31耳）の聴 力の推移 (治療前の聴力レベル $20 \mathrm{~dB}$ 以上, チ ューブ脱落例）チューブ脱落後の聴力を点線で 示す

チューブ脱落後の聴力を点線で示す

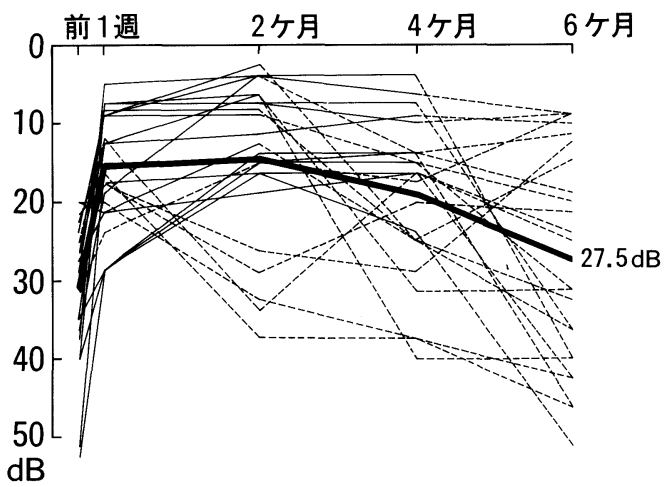

図 5 チューブ留置単独群 (24耳) の聴力の推移 (治療前の聴力レベル $20 \mathrm{~dB}$ 以上, チュー ブ脱落例) 
から著明な聴力改善が得られることは条件 1 と 同様であるが，6 ケ月目で平均聴力の悪化がみ られ，乙れはチューブ脱落例で滲出性中耳炎が 再発したためと考えられる。しかし，本治療法 による 6 ケ月目の平均聴力改善は $17.6 \mathrm{~dB}$ と 満足すべきものであり，聴力改善例は 31 耳中 21 耳（68\%）を占めた(図 4，6).

これに対しチューブ留置単独群（24耳，治療 前の平均聴力レベル $31.3 \mathrm{~dB}$ ) では，4 ケ月目 から聴力が著明に悪化し，6ケ月目の平均聴力 改善はわずかに $3.8 \mathrm{~dB}$ であり, 聴力改善例は 24耳中 8 耳 (33\%) にとどまった(図 5，6)。

次に条件 2 を満たす症例で治療前と治療 6 ケ 月目の聴力とを対応させて比較した (Paired- $\mathrm{t}$ 検定）結果は, 図 7 のように，アデノイド切除 を加えた群では聴力改善が明らかであるが (P <0.01), チューブ留置単独の治療では有意の 改善は認められなかった。

<小 括>

一般にある疾患に対する治療法の効果は, 長 期間の観察により評価されるべきであるが，小 児滲出性中耳炎は加龄による自然治癒の傾向の 強い疾患であるため，むしろ効果が速やかで， 短期間でも確実な効果が得られる治療法も有用 と考えられる. 近年, 滲出性中耳炎の治療法と して頻用されるチューブ留置術は聴力改善がす みやかで確実である点優れている。しかし，今 回の結果から早期にチューブが脱落した症例で は良い聴力が得られず，チューブの存在に依存 する効果であることがわかった。 アデノイド切

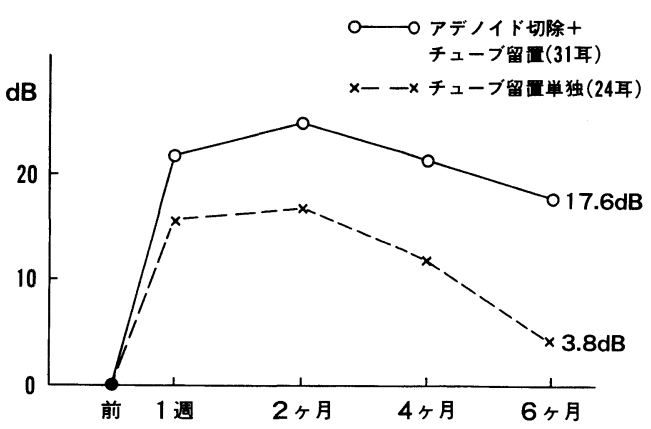

図 6 各治療群の平均聴力改善
除とチューブ留置を組み合わせた治療はその効 果の速効性と確実性は前者之同様の上，チュー ブ脱落例でも 6 ケ月という観察期間では満足す べき聴力改善が得られた。両者の差がアデノイ ド切除の効果，すなわち本手術の滲出性中耳炎 に対する有用性を示すすのと考えられた ${ }^{910)}$.

\section{アデノイドと耳管機能}

アデノイド切除が滲出性中耳炎の有効な治療 法であるととはわかったが，その具体的な機序 を明らかにするには，アデノイドと中耳とをつ なぐ耳管の状態をまず観察する必要がある，小 児滲出性中耳炎例の $81 \%$ で，アデノイドによる 耳管咽頭口の圧迫が見られることは既に述べた が，この場合アデノイドにより耳管の通過性が 障害されているととがまず考えられる．乙の点 を明らかにするため, 以下の 2 つの臨床的観察 を行った。

[観察 1：耳管の受動的開大機能]

<対象と方法 $>$

レ線あるいは内視鏡的にアデノイド肥大を認 めた小児滲出性中耳炎18例 $21 耳 （ 5 \sim 7$ 歳，平

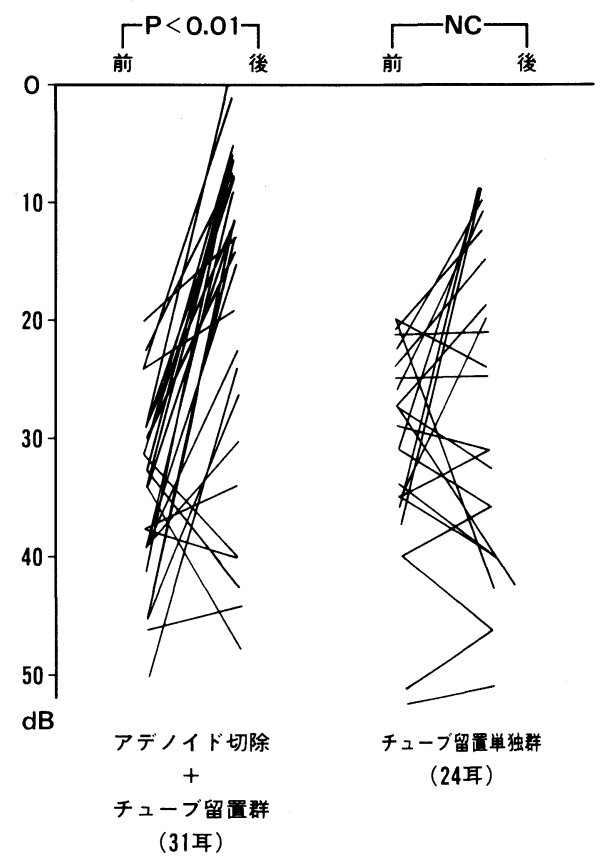

図7 治療前後の聴力の比較 
均6.1歳)について，はじめにチューブ留置術を 行った後，中耳側から耳管に対しての逆通気圧 （受動的耳管開大圧）の測定を行い，ついで全 麻下にアデノイド切除を施行, 手術による炎症, 浮腫などの影響が完全に消退したと考えられる 1 ケ月後に再度耳管の逆通気圧を測定して, 術 前のそれと比較した。

次に，やや長期的な観察として，アデノイド 肥大を伴う滲出性中耳炎111例190耳 ( $5 \sim 7$ 歳, 平均 5. 8歳) のうち, アデノイド切除とチューブ 留置を併用した63例125耳（アデノイド切除群： 平均5.7歳）と，鼓室チューブ留置のみを行った 48例65耳（アデノイド非切除群：平均6.0歳）と で，アデノイド切除術後 2 ケ月目と 6 ケ月目の 耳管の逆通気圧を比較した。また，耳管通気圧 の正常值を外傷性鼓膜穿孔33耳より求め，乙れ と比較した（平均 355 ミリ水柱, 標準偏差 190 ミ リ水柱).

[観察 $2:$ 耳管の能動的開大機能]

<対象と方法 $>$

アデノイド肥大を伴う滲出性中耳炎 111 例 190 耳を，観察 1 と同様にアデノイド切除群（アデ ノイド切除とチューブ留置, 125耳）とアデノイ ド非切除群（チューブ留置のみ，65耳）とに分 け，処置後 1 週間， $2 ， 4 ， 6$ ケ月目に，鼓室 チューブを介して中耳負荷圧のえん下による解
除能を調べた，負加圧は陽圧，陰圧とむに 200 ミリ水柱とし（耳管の通気圧が+200ミリ水 柱以下の場合は，耳管開大が起こらない適当な 加圧), 外傷性鼓膜穿孔33耳の結果加ら, 陽圧負 荷の場合は+200ミリ水柱の圧を数回のえん下 で+100ミリ水柱未満（または負荷圧の $50 \%$ 末 満）まで平衡できる良好群之， +100 ミリ水柱以 上までしか平衡できない不良群に分類した。陰 圧負荷の場合は，負荷したー200ミリ水柱の圧 を少しでも平衡できたものは，残留圧にかかわ らず良好群とした．また 6 ケ月目でチューブ脱 落例のティンパノメトリーを行った。

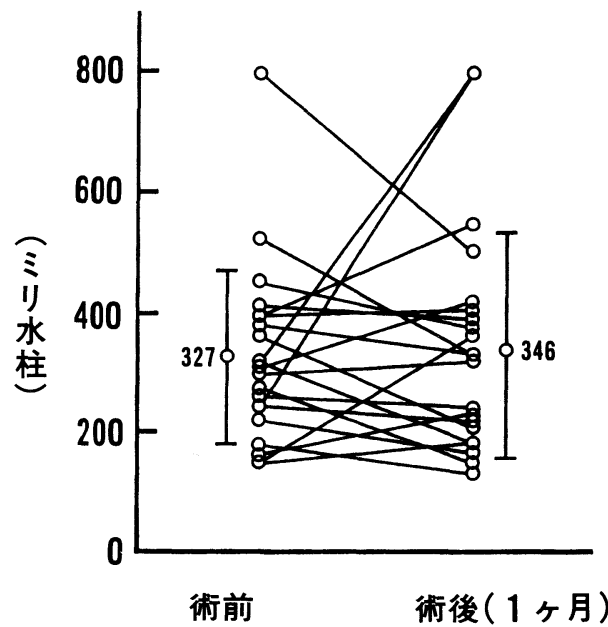

図 8 アデノイド切除前後の耳管通気圧 (21耳)

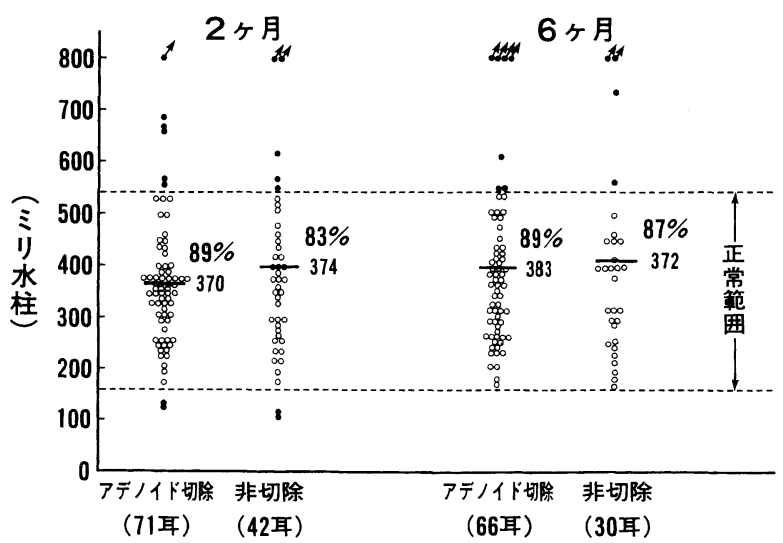

図 9 アデノイド切除術と耳管通気圧（白丸は正常例） 
<結 果 >

[観察 $1:$ 耳管の受動的開大機能]

耳管通気圧をアデノイド切除前，切除後 1 ケ 月目で比較した結果は，切除前では 327 ミ水 柱 (標準偏差147ミリ水柱), 切除後は346ミリ水 柱（標準偏差190ミリ水柱）で，両者間に有意差 を認めなかった（図 8, Paired-t 検定). 次に アデノイド切除群と非切除群との比較は, 術後 2 ケ月での通気圧は，切除群では平均で 370 ミ リ水柱（標準偏差125ミリ水柱），非切除群では 平均 374 ミリ水柱 (標準偏差 157 ミリ水柱)，6 ケ 月目では, 切除群では383ミリ水柱（標準偏差 135 ミリ水柱), 非切除群では372ミリ水柱（標準 偏差 151 ミリ水柱）で，いずれも両者間に有意 の差が認められなかった（図9）。また，両群と 6 $80 \%$ 以上の症例が耳管通気圧の正常範囲 (165 ミリ水柱一 545 ミリ水柱）内に含まれた.

[観察 $2:$ 耳管の能動的開大機能]

アデノイド切除群と非切除群で，えん下によ る耳管の中耳負荷圧解除能を比較した結果，陽 圧負荷では術後 1 週間で, アデノイド切除群で は耳管機能良好が53\%，不良が47\%であるが， 非切除群では良好は $32 \%$ によ゙まり，アデノ イド切除群で有意に良いことがわかった（P< 0. 05, 図10). 術後 2 ケ月, 4 ケ月であ, 切除群 で耳管機能が良い傾向が見られ，術後 6 ケ月で はアデノイド切除群で耳管機能の良好が $61 \%$ ， 非切除群ではこれが30\%にとどまり，アデノイ

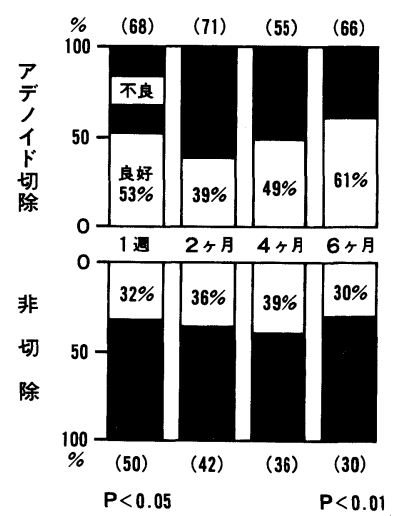

図10 アデノイド切除と耳管の陽圧解除能
ド切除群で有意に耳管の陽圧解除能が良いこと がわかった $(\mathrm{P}<0.01)$.

陰圧負荷ではアデノイド切除群，非切除群間 で有意差はないものの，いずれの時点であ，ア デノイド切除群に良好例が多く見られた(図11)

観察期間中に鼓室チューブが脱落した88耳に ついて，6ケ月目でティンパノメトリーを行っ た結果は,アデノイド切除群ではAタイプ47\%，

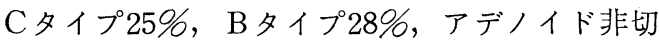
除群ではAタイプ30\%，Cタイプ18\%，Bタイ プ52\%であった(図12). Bタイプにつき，切除 群と非切除群とで有意差を調べたところ，非切 除群に中耳貯留液を示す Bタイプが有意に多い ことがわかった $(\mathrm{P}<0.05)$.

<小 括>

アデノイド切除の前後で耳管の通気圧に差が みられないとと，またアデノイド切除術の前に

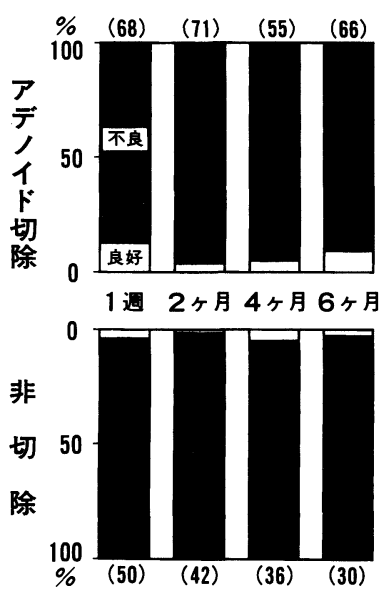

図11 アデノイド切除と耳管の陰圧解除能

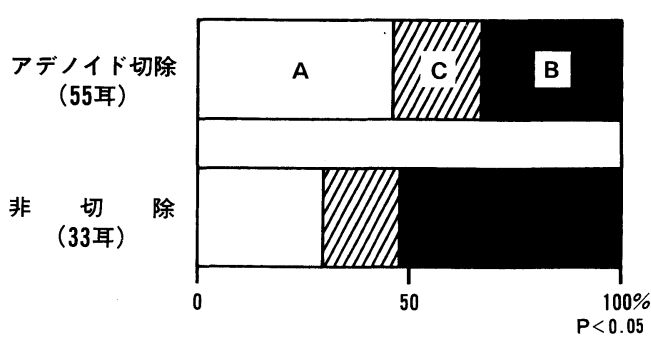

図12 アデノィド切除とティンパノグラムのタイプ 
おいても大多数の症例が正常な耳管の通気圧を 示すととから，アデノイドが耳管に対して少な くとも静的な状態では閉鎖的に働いていないと 考えられた ${ }^{11}$. また, 術後 6 ケ月間の観察から, 長期的にみてもアデノイド切除の耳管通気圧に 対する影響は無いととが示された。内視鏡的に 観察される耳管咽頭口を完全に覆うアデノイド が，mass としての効果を持たず，耳管の通気 性に全く影響を及ぼしていないのはやや考え難 いが,アデノイドが極めて柔らかい組織であり, 単純な耳管の通気性に影響を及ぼすには至らな いものと考えられる. 一方, アデノイド切除が 耳管の動的機能に及ぼす影響はこれと異なり， 術後 1 週目と 6 ケ月目に耳管の陽圧解除能は有 意に改善していることがわかった. 術後 1 週目 で見られた改善は，アデノイド切除の効果だけ でなく，術後に使用される抗生剤の影響屯否定 できないが，術後 6 ケ月目でみられた耳管の陽 圧解除能の改善は切除術そのものによる効果之 考えられる.また 6 ケ月目のティンパノメトリ 一でアデノイド切除群に Bタイプが少なく A夕 イプが多いととも，切除術による総合的な耳管 機能の改善を示すものと言える ${ }^{12)}$ 。乙れらは， アデノイド切除が耳管の圧解除能を改善したと する Bluestone ${ }^{13)}$ ，田島ら ${ }^{14)}$ の報告と一致す る. また, 高橋ら ${ }^{15)}$ は小坚滲出性中耳炎の盛期 と治癒期の耳管機能を比較し, 治癒期で陽圧解 除能が改善することを示しており，てのような アデノイド切除による耳管の圧解除能の改善 は, 滲出性中耳炎の治瘾機転として重要之考え られる. Bluestone らは, アデノイド切除によ りこのような耳管機能の改善が得られるメカニ ズムとして，咽頭陥凹を占めるアデノイドが除 去され，えん下時に生じる耳管咽頭口の圧迫が 改善されるためとしている.あしそのような動 的圧迫の改善が主役をなしているとすれば，術 創が治瘾すれば直ちに安定した耳管機能の改善 が得られる筈であるが，今回の観察で，耳管機 能の改善は, 術後 1 週目を除くと一度悪化し, 術後 6 ケ月で再度改善されており, 即効性では
ない経路を介するととが示唆された。

\section{アデノイド切除と副鼻腔炎}

アデノイドは小児の狭小な上咽頭腔にあって mass としての効果が大きく，乙れが鼻咽腔の 気流動体に与える影響は少なくない。また同時 に鼻・副鼻腔の炎症性疾患の成立とその遷延化 にも無関係ではありえないと考えられる。ここ でアデノイド切除の滲出性中耳炎に対する今一 つの効果として，上気道の慢性炎症の改善を介 する経路を考え，それを反映する副鼻腔炎に対 する効果を観察した。. 従来, 滲出性中耳炎之副 鼻腔炎との関係はいくつか報告されており，我 我の観察でも先述のように小児滲出性中耳炎の 78\%に副鼻腔炎がみられることから，病因論的 に重視されるべきものと考えられる.しかし， アデノイドと副鼻腔炎の関係を検討した報告は 少な(16)17).

<対象と方法 $>$

内視鏡またはレ線的にアデノイド肥大があ り，レ線で副鼻腔炎を認めた小児滲出性中耳炎 例87例 ( $4 \sim 7$ 歳, 平均5.9歳)を, アデノイド 切除群51例 (平均5.9歳) とアデノイド非切除群 36 例 (平均6.0歳) の 2 群に分け, アデノイド切 除前と切除後 6 ケ月〜 1 年での鼻レントゲン （ウォータース法）の所見を比較した. 副鼻腔 炎の程度はレントゲン所見から 4 段階に分類し (表 3), アデノイド切除前後で両側の副鼻腔の 陰影が 2 段階以上改善したものを副鼻腔炎の改 善とし，それ以外を不変とした。また，副鼻腔 炎の改善と耳管機能, 聴力との関係を明らかに するため, アデノイド切除群で副鼻腔炎の改善

表 3 鼻レ線による上顎洞陰影の程度分類

\begin{tabular}{|c|l|}
\hline 程度分類 & \multicolumn{1}{|c|}{ 上頻洞の陰影 } \\
\hline 0 度 & 正 常 \\
1 度 & 軽度粘膜肥厚 \\
2 度 & 自然孔付近に含気腔を残す \\
3 度 & びまん性濃厚陰影 \\
\hline
\end{tabular}


した副鼻腔炎改善群と改善が見られなかった副 鼻腔炎不変群之で, 術後 6 ケ月目の中耳負荷圧 解除能（陽圧負荷）之平均聴力（治療前の聴力 レベル $20 \mathrm{~dB}$ 以上, 早期チューブ脱落例)を比 較した。

\section{<結 果>}

アデノイド切除群では, 副鼻腔炎の改善率は 57\%に達し，不変は $43 \%$ あ゙あった。一方非切除 群では改善28\%，不変72\%であり，アデノイド 切除群で有意に副鼻腔炎の改善がみられた (P $<0.01$, 図13).

次にアデノイド切除群で，副鼻腔炎改善例と 不変例で耳管の陽圧解除能を比較した所, 改善 群では耳管機能良好 $73 \%$, 不良 $27 \%$ であり，不 変群では耳管機能良好 $40 \%$, 不良 $60 \%$ で，改善 群で耳管機能が有意に良いととがわかった $(\mathrm{P}$ $<0.05$, 図14). また, 聴力の面から両群を比較 すると, 副鼻腔炎改善群では鼓室チューブの脱 落にもかかわらず安定した聴力改善が得られ，

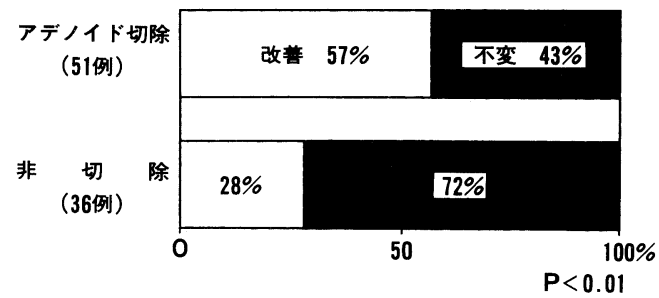

図13 アデノイド切除と副鼻腔炎の改善

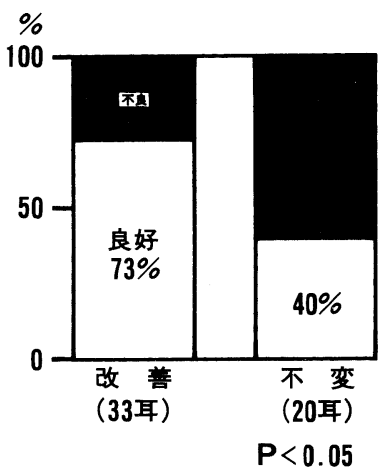

図14 副鼻腔炎の改善の有無と陽圧解除能 (アデノイド切除例)
6 ケ月目の平均聴力は $11.7 \mathrm{~dB}$ ，聴力改善は $26.9 \mathrm{~dB}$ に達した(図15). 一方不変群では術後 6 ケ月で平均聴力の悪化がみられ $(23.2 \mathrm{~dB})$, 聴力改善は $11.7 \mathrm{~dB}$ にとどまった.

<小括 $>$

アデノイド切除群で有意に副鼻腔炎が改善し たことは，本手術が鼻咽腔の慢性炎症を消退に 向かわせたととを示すむのといえる12)。また， 副鼻腔炎の改善した群で良好な耳管機能と聴力 の改善が得られたととから，アデノイド切除が 鼻咽腔の炎症を改善し，これにより耳管機能が 改善され，滲出性中耳炎を治瘾に向かわせた経 路が示唆された。乙れはアデノイド切除による 耳管の動的機能の改善が即効性ではなく，効果 の発現にある程度の期間を要した事実ともよく 合致する. しかし，一方ではアデノイド切除が 耳管機能と副鼻腔炎とに独立して働いている可 能性むあり，現段階では副鼻腔炎の改善が直ち に耳管機能の改善につながるか否かは結論を出 しがたい.

\section{難治例についての検討}

アデノイド切除術が滲出性中耳炎あるいは鼻 咽腔の炎症を治瘾に向かわせることはわかった が，臨床的にはこれら外科的治療にも抵抗して 難治の経過をとる症例も稀ではない。乙れら難 治例の病態を知ることは，アデノイド切除術の 限界を知ると共に，本手術の作用機転を知るう えでも重要と考えられる．特に乳突蜂巣の発育 抑制例，鼓膜の陥凹や瘾着が著明な例で治療に

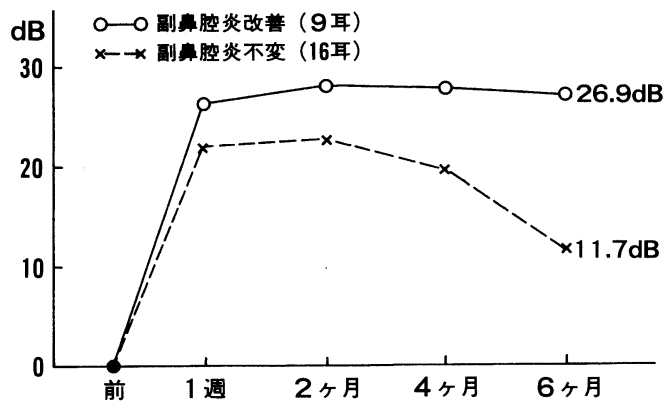

図15 副鼻腔炎の改善の有無と平均聴力改善 (アデノイド切除例) 
難渋するととが多く ${ }^{18)} ，$ これらとアデノイド切 除術の予後との関係について検討した。

<対象と方法 $>$

アデノイド切除とチューブ留置または鼓膜切 開の併用で治療された小児滲出性中耳炎のう ち， 1 年以内にチューブが脱落し，かつ術後 1 年以上経過観察の行えた65例125耳（ 5 〜 歳) から次の 2 群を選んだ.

1. 難治群: 術後 1 年目で中耳に貯留液が確 認され，明らかに滲出性中耳炎の再発がみられ た症例16例 31 耳 ( $5 \sim 7$ 歳, 平均 5.5 歳).

2. 治癮群: 術後 1 年目で少なくとも 3 ケ月 間，聴力，鼓膜所見，ティンパノグラムともに 正常で，滲出性中耳炎が治癒したと考えられる 症例 35 例70耳 ( $5 \sim 7$ 歳, 平均 5.7 歳).

これら 2 群につき, 以下の観察を行った.

[観察 1 : アデノイド肥大の有無]; 上咽頭側 面レ線および内視鏡による。

[観察 2 : 副鼻腔炎の有無]; 鼻レ線（ウォー タース法）による.

[観察 3 : 治療前の聴力レベル]; 純音聴力 4 分法による.

[観察 4：鼓膜陥凹の 程度]; 拡大耳鏡または 処置用顕微鏡で鼓膜の弛緩部之緊張部とに分け て記載した. 弛緩部については, 正常〜軽度陥凹 (Tos 分類 1 度) を軽度, 鼓膜弛緩部とつち骨に 癒着がみられる例 (Tos 分類 2 度)，さらには 鼓膜弛緩部周囲の骨吸収のみられる症例（Tos 分類 3 〜 度) を高度陥凹とした(図16). 緊張

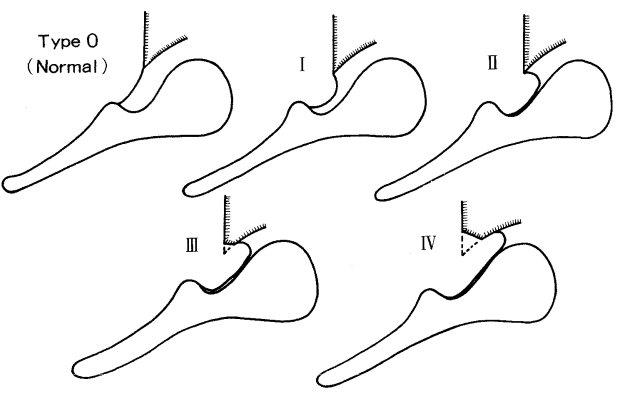

(by M. Tos 1980)

図16弛緩部陥凹の分類
部については，正常〜軽度陥凹を軽度，鼓膜緊 張部之岬角あるいはアブミ骨の上部が接触して いるあのを高度とした。

[観察 5 : 乳突含気蜂巣容積]; 乳突含気腔を, 耳レ線（シューラー法）から面積としてデジタ イザーでコンピューター計測を行った。 また対 照として，耳疾患を認めない 5 ～歳の小児 （各年齢 5 例 10 耳，合計 30 耳）について同様の 測定を行った.

<結 果 >

[観察 $1:$ ア アデノイド肥大の有無]

難治群, 治癒群とも全例でアデノイド肥大が 認められ，両群間で差はみられなかった。

[観察 2 : 副鼻腔炎の有無]

難治群の56\%，治瘾群の83\%で副鼻腔炎が認 められ，両群間に有意差は認められなかった が，むしろ難治群でやや副鼻腔炎の頻度が低い 傾向がみられた。

[観察 $3:$ 治療前の聴力レベル]

難治群で平均 $37.1 \mathrm{~dB}$ (標準偏差 $11 \mathrm{~dB}$ ), 治 瘾群では平均 $26.0 \mathrm{~dB}$ (標準偏差 $10 \mathrm{~dB}$ ) であ り，難治群で聴力が悪い傾向がみられた（P< 0.01, 図17). 特に聴力レベル $40 \mathrm{~dB}$ 以上の症 例は, 治癒群の $8 \%$ に対して難治群では $39 \%$ と 多数にみられた。

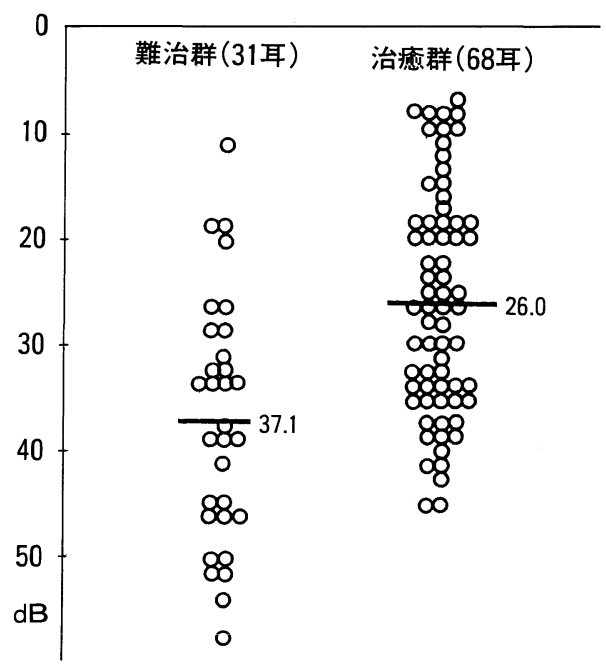

図17 治療前の聴力の比較 
[観察 4：鼓膜陥凹の程度]

鼓膜弛緩部に高度の陥凹がみられる症例は， 難治群の $10 \%$, 治癒群の $5 \%$ といずれあ少数で あった(表 4)。また，難治群の 1 耳で弛緩部周 囲の骨吸収が認められた。一方, 鼓膜緊張部で は難治群の $52 \%$ で高度陥凹が認められ，治療群 の $5 \%$ と比べて有意に高いことがわかった $(\mathrm{P}$ $<0.05)$.

\section{[観察 5:乳突含気蜂巣面積]}

難治群で平均 $4.7 \mathrm{~cm}^{2}$ (標準偏差 $1.3 \mathrm{~cm}^{2}$ ), 治 癒群で平均 $8.3 \mathrm{~cm}^{2}$ (標準偏差 $2.9 \mathrm{~cm}^{2}$ ), 対照群 では平均 $9.8 \mathrm{~cm}^{2}$ (標準偏差 $2.5 \mathrm{~cm}^{2}$ ) であり, 難治群で有意に乳突腔の発育が抑制されている ことがわかった（P<0.01，図18). また，対照 群の平均値之標準偏差 (2SD) を考慮し, 蜂巣面 積の正常值を $4.8 \mathrm{~cm}^{2} \sim 14.8 \mathrm{~cm}^{2}$ とすると，小 児滲出性中耳炎で乳突腔の発育が正常な例は, アデノイド切除とチューブ留置の組み合わせで 83\% と大半が治癒するが，発育の抑制された症 例では，77\%と過半数の症例で難治の経過をと るととがわかった。

\section{<小 括>}

小児滲出性中耳炎で, 乳突含気腔の発育が悪 く，鼓膜の陥凹が著明な症例は，アデノイド切 除に抵抗する難治例であることが確認された。

また，難治群で治療前の聴力レベルがやや悪い ことは，乙れら乳突腔や鼓膜の病変が高度であ るためと考えられた．従来，アデノイド切除術 の本疾患に対する効果が予期したほどではない 理由の 1 つとして，アデノイド切除の適応が明 確でなかったてとがあげられる。今回の結果か

表 4 各群における鼓膜陥凹の比較

\begin{tabular}{|c|c|c|c|c|}
\hline & \multicolumn{2}{|c|}{ 弛 緩 部 } & \multicolumn{2}{|c|}{ 緊 張 部 } \\
\hline & 高 度 & 軽 度 & 高 度 & 軽 度 \\
\hline $\begin{array}{l}\text { 難治群 } \\
\text { (31耳) }\end{array}$ & $10 \%$ & $90 \%$ & $52 \%$ & $48 \%$ \\
\hline $\begin{array}{l}\text { 治癒群 } \\
\text { (60耳) }\end{array}$ & $5 \%$ & $95 \%$ & $5 \%$ & $95 \%$ \\
\hline
\end{tabular}

ら，アデノイド切除術は乳突含気腔の発育不良 例での効果は不十分で，蜂巣発育の正常な例で 有効な治療と考えることができる，乙のととか ら本手術による滲出性中耳炎の治療に限界のあ ることは明らかで，難治例ではアデノイド切除 よりむしろ長期留置型チューブによる治療が合 理的といえる．また，本術式の作用機転から考 えると，乙れらの難治例ではアデノイド切除に より改善されない鼻咽腔の炎症，あるいは先天 性の耳管機能不全などが予測され ${ }^{18)}$ ，今後明ら かにすべき問題と考えられる.

\section{まとめ}

はじめにアデノイド切除の滲出性中耳炎に対 する効果を, 純音聴力の改善の面からみたとと ろ，設定したどの条件下であアデノイド切除の 有効性が明らかになった。従来，その効果が疑 問視された来たのは，一つにはアデノイド切除 が即効的でない点もあるが，効果の判定が鼓膜 所見などの主観的なものか，ティンパノグラム など false positive の因子が入りやすい検査に

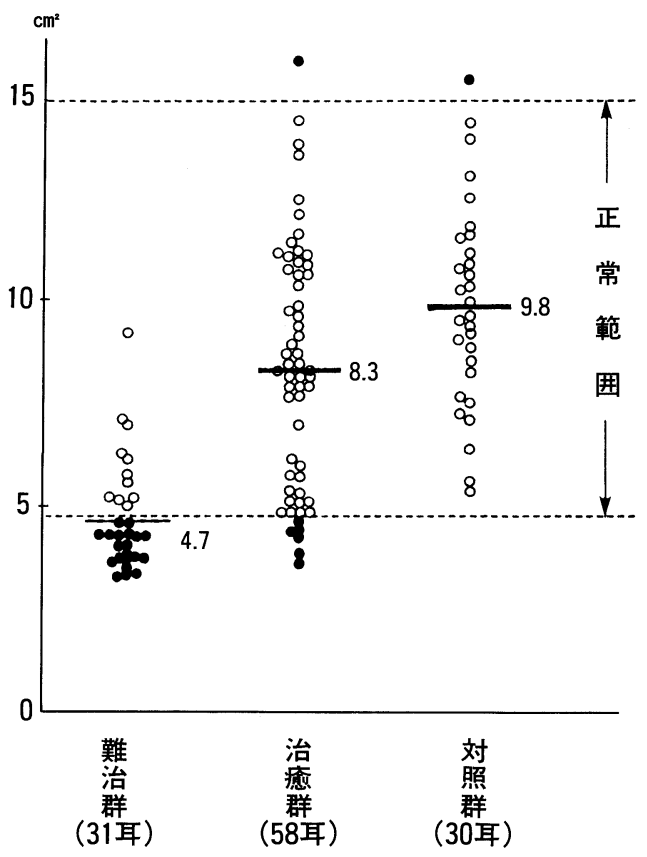

図18 乳突蜂巣面積の比較 
基づいたこと，対象患児の年齢が滲出性中耳炎 発症の盛期に限られず，観察期間む長期で自然 治癒の因子が無視できなかったためと考えた.

一方，アデノイドと耳管との関係を耳管の通 気性の観点から調べたとてろ，予想された様な アデノイドの耳管に対する圧迫はないととがわ かった．乙れは一見 mass としてのアデノイド が耳管を閉塞しているようにみえても，乙の圧 力は問題となるようなものでなく，耳管の静的 な通気性には影響を及ぼしてはいないととを示 すむのといえる。しかし耳管のえん下による開 大能についてはアデノイドは障害的に働いてお り，アデノィド切除によりこの動的な耳管機能 が著明に改善するととがわかった。 また，ての 効果は発現までに約 6 ケ月の期間を要し, 従来 の物理的観点からは，アデノイド切除術が即効 的でない理由を解噃することは困難といえる. この意味から，アデノィド切除による副鼻腔炎 の著明な改善率に注目すべきであり，アデノイ ドという炎症性, あるいは物理的な mass が消 失したととによる, 鼻咽腔の炎症病態の改善が 耳管機能を 2 次的に改善し，滲出性中耳炎の軽 快につながる経路が考えられた。しかし，アデ ノイド切除が耳管之副鼻腔炎にそれぞれ独立に 作用する可能性むあり，今後検討を要する課題 と考えられた.

一方, 鼓膜の陥凹が高度で乳突含気腔の発育 が悪い症例は，アデノイド切除に抗する難治例 であることが明らかにされ，乙れらの症例では アデノイド切除よりむしろ, 長期留置型チュー ブによる治療が有用と考えられた。

いずれにせよアデノイドの肥大が滲出性中耳 炎にマイナスの因子として働くことは疑いな く, 欧米に比べ切除術の施行頻度の少ない本邦 に抢いては，本手術に対する批判的な論調に左 右されることなく, 客観的な検査により適応が あれば，積極的にアデノイド切除術を行うべき と考える。

\section{文献}

1) Meyer W: On adenoid vegetations in the nasopharyngeal cavity. Med Surg Trans(London) $53: 191 \sim 215,1870$.

2) Rynnel-Dagöö B, Ahlbom A and Schiratzki H : Effects of adenoidectomy; a controlled twoyear follow-up. Ann Otol Rhinol Laryngol 87 : $272 \sim 278,1978$.

3) Roydhouse $\mathrm{N}$ : Adenoidectomy for otitis media with mucoid effusion. Ann Otol Rhinol Laryngol 89 Suppl $68:$ 312 315, 1980.

4) Fiellau-Nikolajsen $M$ : Tympanometry and secretory otitis media. Acta Otolaryngol Suppl $394: 1 \sim 73,1983$.

5) McKee WJE : A controlled study of the effects of tonsillectomy and adenoidectomy in children. Brit J Prev Soc Med $17:$ 49 69, 1963.

6) Maw AR, Jeans WD and Cable HR: Adenoidectomy; a prospective study to show clinical and radiological changes two years after operation. J Laryngol Otol $97: 511 \sim 518,1983$.

7) Bulman $\mathrm{CH}$, Brook $\mathrm{SJ}$ and Berry $\mathrm{MG}: \mathrm{A}$ prospective randomized trial of adenoidectomy vs grommet insertion in the treatment of glue ear. Clin Otolaryngol $9: 67 \sim 75,1984$.

8) 本庄 祳：鼻咽腔(アデノイド・耳管)との関係; 特集 滲出性中耳炎一最新の知見一, 耳喉 56 : $771 \sim 778,1984$.

9 ) 藤田明彦, 高橋晴雄, 本庄 踙, 他 : 小览滲出性 中耳炎とアデノイド切除術一聴力の面から一。耳 喉 $59: 6 ; 457 \sim 460,1987$.

10）藤田明彦, 高橋晴雄, 本庄 脤, 他 : 小児滲出性 中耳炎に対するアデノイド切除術の効果. 耳展 $30: 5 ; 583 \sim 587,1987$.

11）高橋晴雄, 林 正彦, 本庄 䉷: アデノイドと耳 管機能. 耳展 $30: 1 ; 43 \sim 46,1987$.

12）藤田明彦, 高橋晴雄, 本庄 嚴, 他: 小览滲出性 中耳炎とアデノイドー耳管機能・副鼻腔炎の面か ら一. 耳展 $30: 2 ; 237 \sim 241,1987$.

13) Bluestone CD, Cantekin EI and Beery QC : Certain effects of adenoidectomy on eustachian tube ventilatory function. Laryngoscope 85 : 113 127, 1975.

14）田島和幸, 三苫藤吉郎, 本庄 嚴, 他 : アデノイ 
ド切除の耳管機能に及ぼす影響. 耳鼻臨床 79 : 729 733, 1986.

15）高橋晴雄, 林 正彦, 本庄 篇, 他 : 治癒期滲出 性中耳炎の耳管.耳展 $29: 657 \sim 661 ， 1986$.

16）古和田勲：小览副鼻腔炎と中耳炎. 耳喉 $52: 559$ 〜 566, 1980.

17) Grote JJ and Kuijpers W : Middle ear effusion and sinusitis. J Laryngol Otol $94: 177 \sim 183$, 1980.

18）藤田明彦, 高橋晴雄, 本庄 厳, 他: 滲出性中耳 炎難治例の検討.耳鼻臨床 $81: 363 \sim 371 ， 1988$.

(原稿採択：昭和63年 8 月 13 日 別刷請求先 : 藤田明彦

T710 倉敷市美和1-1-1 倉敷中央病院耳鼻咽喉科 